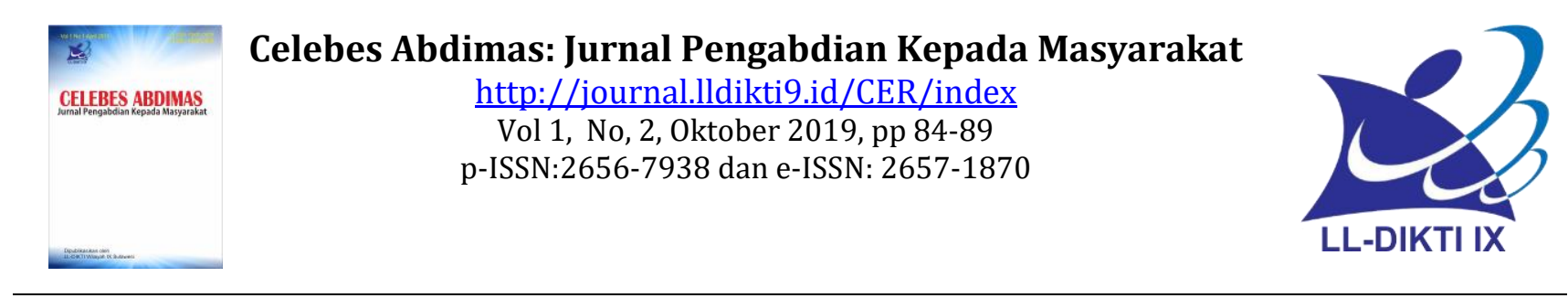

\title{
Pemanfaatan Information dan Comunication Technology (ICT) Pada SLB Negeri 2 Makassar
}

\author{
Dolly Indra 1, Umar Mansyur ${ }^{2}$, Ramdan Satra ${ }^{3}$ \\ 1 Program Studi Sistem Informasi, Universitas Muslim Indonesia \\ Email: dolly.indra@umi.ac.id \\ 2 Prodi Pendidikan dan Sastra Indonesia, Universitas Muslim Indonesia \\ Email: umar.mansyur@umi.ac.id \\ 3 Program Studi Informatika, Universitas Muslim Indonesia \\ Email: ramdan.satra@umi.ac.id
}

\section{Artikel info}

\section{Artikel history:}

Received;Agustus-2019

Revised: September-2019

Accepted;Oktober-2019

Publish: Oktober-2019

\begin{abstract}
Mitra pengabdian ini adalah Sekolah Luar Biasa Negeri 2 Makassar. Permasalahan mitra adalah belum adanya informasi berbasis online untuk penyebaran informasi sekolah dan metode pengajaaran masih bersifat konfensional. Pengabdian ini bertujuan melakukan pengabdian dengan menerapkan ICT pada proses belajar mengajar guru dan pembuatan website informasi sekolah. Metode yang digunakan dalam pengabdian ini adalah penerapan ICT dalam proses belajar mengajar dengan membuatkan aplikasi berbasis Mobile Android dan pembuatan webiste informasi sekolah. Pada pengabdian ini dilakukan juga pendampingan bagi guru dan admin webiste desa untuk melatih mengoperasikan aplikasi pembelajarn berbasis mobile dan penginputan informasi pada webiste sekolah . Hasil pengabdian ini adalah telah menerapkan ICT pada sekolah SLB N 2 Makassar. Penerapan ICT pada SLB N 2 Makassar yaitu berupa website http://slbn2makassar.sch.id/ dan aplikasi berbasis Mobile Android dengan nama aplikasi UMIBISA. Hasil pengambilan data pengguna website dan aplikasi menunjukan bahwa penguna merasa tertarik dengan website dan aplikasi dan mereka mudah dalam menggunakan aplikasi dan website tersebut.
\end{abstract}

\footnotetext{
Keywords:

Multimedia;

SLB;

Website; aplikasi;

pemanfaatan
}

Coresponden author:

Email: ramdan@umi.ac.id

Jalan Dr. J. Leimena No.130 Tello Baru Panakkukang, Makassar artikel dengan akses terbuka dibawah lisensi CC BY -4.0

\section{PENDAHULUAN}

Perkembangan teknologi telekomunikasi dan informasi memungkinkan kemudahan dalam melakukan kegiatan sekolah dan interaksi antara guru dan murid dan kegiatan belajar murid di sekolah, serta hubungan pihak sekolah dengan masyarakat luas. Salah satu penunjang aktivitas 
di sekolah adalah Information and Communication Technology (ICT), seperti website sekolah, media pembelajaran berbasis multimedia yang dapat membantu terciptanya pembelajaran secara interaktif. Dengan adanya website sekolah, masyarakat bisa mendapatkan informasi tentang sekolah tersebut dengan mudah.

Menurut Akbar dan Tjendrowaseno (2015), bahwa dengan adanya web sekolah, penyampaian informasi kepada masyarakat luas bias lebih efektif dan efisien sementara menurut Dolly Indra dan Lilis Nurhayati (2018), bahwa dengan adanya website dapat memperluas jaringan. Pihak sekolah dapat menambahkan atau merubah informasi tentang profilnya atau informasi yang penting diketahui oleh masyarakat. Melalui website, sekolah juga dapat lebih interaktif dengan masyarakat.

Information and Communication Technology (ICT) dapat pula digunakan sebagai media pembelajaran yang interaktif, misalnya aplikasi multimedia. Aplikasi multimedia merupakan aplikasi yang dirancang dengan menggabungkan elemen suara, gambar, video, serta dokumen.

Beberapa penelitian untuk pengembangan kemampuan siswa SLB telah dilakukan. Beberapa penelitian tersebut diantaranya adalah penelitian yang dilakukan oleh Mutia dan Desiningrum (2015), mengajarkan kata-kata kepada siswa SLB tunarungu yang dipadukan dengan gambar. Begitupula dengan penelitian yang dilakukan oleh Sejati dan Yumpi-R (2016), memadukan visual dan audiotori pada siswa untuk meningkatkan kemampuan dalam mengingat huruf alfabet. Hasil penelitian yang dilakukan oleh Sejati dan Yumpi-R (2016) menunjukkan peningkatan kemampuan meningat huruf dari siswa setelah dilakukan eksperimen. Kemudian penelitian terbaru yang dilakukan oleh Setyawati (2018), dengan melakukan pengenalan huruf dan kata kepada anak tunagrahita ringan. Hasil penelitian tersebut menunjukan kemampuan membaca anak tunagrahita ringan setelah dilakukan pengujian.

Mitra pengabdian ini yaitu SLB N 2 Makassar dalam penyebaran informasi sekolahnya belum menggunakan website sebagai sarananya, hal ini menyebabkan keberadaan sekolah tersebut tidak banyak diketahui oleh masyarakat. Kemudian dalam proses belajar mengajar dikelas belum menerapkan ICT yang menyebabkan efisiensi pengajaran kurang bagus. Penerapan ICT dalam proses belajar mengajar di kelas diharapkan dapat memberikan nilai tambah dan efisinesi proses belajar mengajar guru di kelas.

Berdasarkan analisis situasi maka diusulkan pembuatan sistem berbasis Information and Communication Technology (ICT) di Sekolah Luar Biasa (SLB) Negeri 2 Makassar berupa website sekolah sehingga diharapkan pihak sekolah dapat mengembangkan sekolah nantinya dan juga sumber daya yang ada di Sekolah dan lingkungan sekitarnya. Selain website, diusulkan pula pembuatan aplikasi multimedia untuk pengenalan nama seperti buah, hewan, sayur dan huruf lontara serta kuis.

\section{Metode}

Sekolah Luar Biasa (SLB) Negeri 2 Makassar merupakan mitra yang terletak di jalan Pahlawan no. 100 kabupaten Bulurokeng, kecamatan Biringkanaya di kota Makassar. Sekolah Luar Biasa (SLB) Negeri 2 Makassar sebagai mitra belum memiliki media informasi yang dapat diakses oleh masyarakat luas. Untuk mengatasi masalah tersebut maka dirancang aplikasi berbasis web yang dapat diakses oleh masyarakat melalui media internet menggunakan perangkat komputer atau perangkat mobile. Selain permasalahan media informasi, akan dibangun juga aplikasi multimedia yang dapat membantu sebagai media pembelajaran. Penggunaan aplikasi multimedia sebagai media pembelajaran, diharapkan dapat membantu guru dalam proses belajar mengajar. 
Melakukan pelatihan terhadap 10 guru yang bertujuan agar supaya guru mempunyai pengetahuan dasar tentang cara pengoperasian aplikasi website, pemeliharaannya serta cara pengelolaannya serta melakukan seminar tentang Information and Communication Technology (ICT) yang bertujuan untuk menambah wawasan pimpinan dan guru di sekolah Luar Biasa (SLB) Negeri 2 Makassar.

Pada pengabdian ini juga dilakukan pengambilan data terkait pengguanaan aplikasi dan website sekolah. Pemgambilan data ini dilakukan dengan metode kuesioner penggunaan website dan aplikasi kepada guru-guru, karyawan, dan admin website. Hasil pengambilan data ini nanti akan dilihat persentasi tingkat kepuasan pengguna terhadap penerapan ICT di sekolah tersebut.

\section{Hasil Dan Pembahasan}

Hasil pelaksanaan kegiatan pengabdian kepada masyarakat (PKM) pada Sekolah Luar Biasa (SLB) Negeri 2 Makassar berupa pelatihan dan seminar sementara untuk produk yang dihasilkan berupa website dan UMIBISA.

Pada pelatihan ini dilakukan pendampingan dan pengajaran proses penggunaan aplikasi UMIBISA, admin website, pembuatan materi ajar berbasis sparkol dan pemaparan materi proses belajar mengajar yang baik seperti yang ditunjukkan pada gambar 1 .

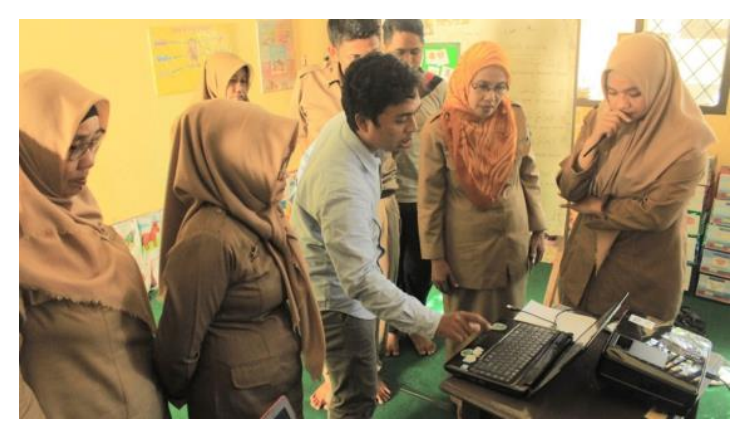

Gambar 1: Tim Memberikan Pelatihan Aplikasi UMIBISA, Website dan Pembuatan materi berbasis sparkol

Seminar ini dilakukan untuk menjelaskan secara umum program pengabdian yang dilakukan. Pada seminar ini dilakukan juga Lauching Website Sekolah Luar Biasa (SLB) Negeri 2 Makassar. Pada seminar ini dihadiri oleh pimpinan, guru staf dan para siswa seperti yang ditunjukkan pada gambar 2 .

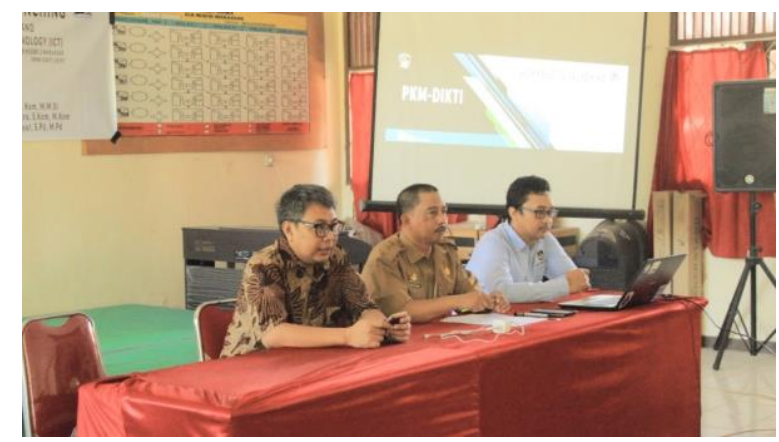

Gambar 2: Tim Memberikan Seminar dan Launching Website Sekolah Luar Biasa (SLB) Negeri 2 Makassar 
87| Celebes Abdimas: Jurnal Pengabdian Kepada Masyarakat

Produk yang dihasilkan kegiatan pengabdian kepada masyarakat (PKM) pada Sekolah Luar Biasa (SLB) Negeri 2 Makassar berupa website dengan alamat situsnya adalah http://slbn2makassar.sch.id/ dan aplikasi UMIBISA menampilkan informasi tentang buah, hewan, sayur dan huruf lontara serta kuis, seperti yang ditunjukkan pada gambar 3.

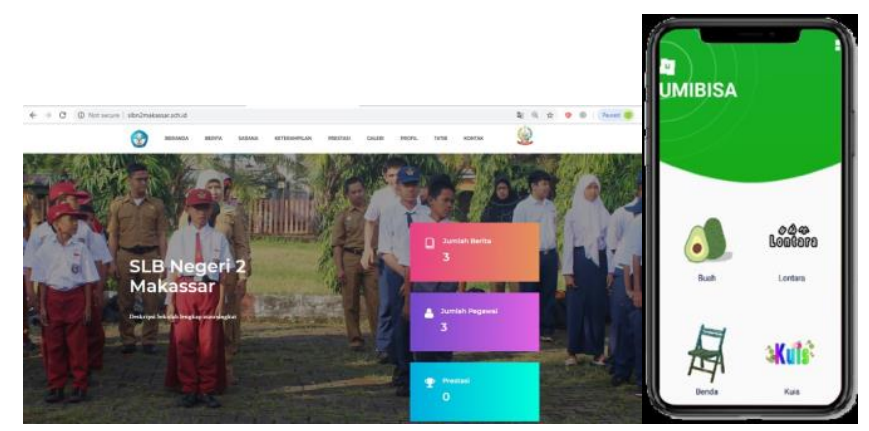

Gambar 3: Website dan Aplikasi UMIBISA

Produk yang dihasilkan dalam pengabdian kepada masyarakat (PKM) tersebut kemudian dilakukan pengambilan angket terhadap para guru yang berjumlah masing-masing 30 guru untuk penggunaan website dan aplikasi UMIBISA yang ditunjukkan pada tabel 1 dan tabel 2.

Tabel 1. Angket Penggunaan Website

\begin{tabular}{|c|c|c|c|c|c|c|}
\hline NO & Pertanyaan & SS & $S$ & $\mathrm{C}$ & $\mathbf{K S}$ & TS \\
\hline 1 & $\begin{array}{l}\text { Apakah Website www.slb2makassar.sch.id memiliki } \\
\text { interaksi yang jelas dan dapat dimengerti oleh anda? }\end{array}$ & $27 \%$ & $56 \%$ & $17 \%$ & & \\
\hline 2 & $\begin{array}{l}\text { Apakah menu pada website www.slb2makassar.sch.id } \\
\text { mudah untuk diakses? }\end{array}$ & $17 \%$ & $53 \%$ & $27 \%$ & $3 \%$ & \\
\hline 3 & $\begin{array}{l}\text { Apakah Tampilan website www.slb2makassar.sch.id } \\
\text { menarik bagi anda? }\end{array}$ & $33 \%$ & $37 \%$ & $30 \%$ & & \\
\hline 4 & $\begin{array}{l}\text { Apakah Web www.slb2makassar.sch.id Mudah } \\
\text { dipelajari dan } \\
\text { dioperasikan pada perangkat Gadget Anda? }\end{array}$ & $27 \%$ & $56 \%$ & $17 \%$ & & \\
\hline 5 & $\begin{array}{l}\text { Apakah informasi yang ditampilkan pada } \\
\text { www.slb2makassar.sch.id jelas dan terperinci? }\end{array}$ & $3 \%$ & $47 \%$ & $47 \%$ & $3 \%$ & \\
\hline 6 & $\begin{array}{l}\text { Apakah informasi yang ditampilkan pada } \\
\text { www.slb2makassar.sch.id dapat mewakili } \\
\text { ketidaktahuan anda? }\end{array}$ & $13 \%$ & $57 \%$ & $30 \%$ & & \\
\hline 7 & $\begin{array}{l}\text { Apakah tingkat kecepatan untuk mengakses website } \\
\text { www.slb2makassar.sch.id cukup baik? }\end{array}$ & $3 \%$ & $54 \%$ & $43 \%$ & & \\
\hline 8 & $\begin{array}{l}\text { Apakah pada website www.slb2makassar.sch.id } \\
\text { terdapat } \\
\text { layanan konsultasi online? Jika ada, apakah hal itu } \\
\text { memudah- } \\
\text { kan bagi anda? }\end{array}$ & $20 \%$ & $63 \%$ & $17 \%$ & & \\
\hline 9 & $\begin{array}{l}\text { Apakah website www.slb2makassar.sch.id mudah } \\
\text { untuk }\end{array}$ & $17 \%$ & $53 \%$ & $30 \%$ & & \\
\hline
\end{tabular}


dioperasikan?

10 Apakah website www.slb2makassar.sch.id memiliki tampilan yang menarik?

$27 \% \quad 46 \% \quad 27 \%$

Berdasarkan Tabel 1 diatas, penggunaan website untuk para guru menghasilkan tingkat rata-rata sangat setuju (SS) adalah 19\%, setuju (S) adalah 52\%, cukup (C) adalah 29\%, kurang setuju (KS) adalah $1 \%$ dan tidak setuju (TS) adalah $0 \%$.

Tabel 2. Angket Penggunaan Aplikasi UMIBISA

\begin{tabular}{|c|c|c|c|c|c|c|}
\hline NO & Pertanyaan & SS & $\mathbf{S}$ & C & KS & TS \\
\hline 1 & $\begin{array}{l}\text { Apakah aplikasi UMIBISA dapat membantu proses } \\
\text { belajar } \\
\text { anak? }\end{array}$ & $53 \%$ & $47 \%$ & & & \\
\hline 2 & $\begin{array}{l}\text { Apakah aplikasi UMIBISA mudah untuk dipelajari dan } \\
\text { dioperasikan? }\end{array}$ & $30 \%$ & $50 \%$ & $20 \%$ & & \\
\hline 3 & $\begin{array}{l}\text { Apakah menu pada aplikasi UMIBISA membosankan } \\
\text { saat } \\
\text { digunakan? }\end{array}$ & $23 \%$ & $23 \%$ & $20 \%$ & $14 \%$ & $20 \%$ \\
\hline 4 & $\begin{array}{l}\text { Apakah menu pada aplikasi UMIBISA mudah untuk } \\
\text { digunakan? }\end{array}$ & $37 \%$ & $60 \%$ & $3 \%$ & & \\
\hline 5 & $\begin{array}{l}\text { Apakah tampilan desain dan warna aplikasi UMIBISA } \\
\text { menarik? }\end{array}$ & $50 \%$ & $43 \%$ & $7 \%$ & & \\
\hline 6 & $\begin{array}{l}\text { Apakah anda mudah untuk melakukan pindah menu } \\
\text { dari satu } \\
\text { menu ke menu lainnya pada aplikasi UMIBISA? }\end{array}$ & $40 \%$ & $43 \%$ & $17 \%$ & & \\
\hline 7 & $\begin{array}{l}\text { Apakah gambar yang disajikan dapat dengan mudah } \\
\text { dikenali? } \\
\text { Apakah aplikasi ini menyajikan konten edukasi yang }\end{array}$ & $33 \%$ & $40 \%$ & $27 \%$ & & \\
\hline 8 & $\begin{array}{l}\text { layak } \\
\text { untuk siswa? }\end{array}$ & $40 \%$ & $53 \%$ & $7 \%$ & & \\
\hline 9 & $\begin{array}{l}\text { Apakah media pembelajaran aplikasi UMIBISA dapat } \\
\text { dijadikan } \\
\text { sebagai media bantu belajar? }\end{array}$ & $53 \%$ & $40 \%$ & $7 \%$ & & \\
\hline 10 & $\begin{array}{l}\text { Apakah media pembelajaran aplikasi UMIBISA sudah } \\
\text { cukup } \\
\text { baik? }\end{array}$ & $43 \%$ & $47 \%$ & $10 \%$ & & \\
\hline
\end{tabular}

Berdasarkan Tabel 2 diatas, penggunaan aplikasi UMIBISA untuk para guru menghasilkan tingkat rata-rata sangat setuju (SS) adalah 40\%, setuju (S) adalah 45\%, cukup (C) adalah $12 \%$, kurang setuju (KS) adalah $1 \%$ dan tidak setuju (TS) adalah $2 \%$.

\section{Simpulan Dan Saran}

Kegiatan kegiatan pengabdian kepada masyarakat (PKM) pada Sekolah Luar Biasa (SLB) Negeri 2 Makassar ini telah menerapkan aplikasi berbasis mobile dengan platform Android bernama UMIBISA dan implementasi website sekolah. Pengabdian ini telah dilakukan 
pendampingan penggunaan aplikasi UMIBISA dan pelatihan Admin website. Hasil responden penggunaan aplikasi UMIBISA dan webisite menunjukan bahwa aplikasi dan website yang dibuat mendapatkan respon yang baik dari pengguna. Pengguna tertarik dengan tampilan aplikasi dan website dan penggunaan sebagian responden mengatakan baik. Hal ini menunjukan penerapan ICT yang telah dilakukan telah sukses dalam proses penggunaan dan tampilannya.

\section{Ucapan Terima Kasih}

Terima kasih disampaikan kepada Kemenristekdikti atas bantuan dananya untuk program pengabdian kepada masyarakat kompetitif nasional program kemitraan masyarakat tahun 2019.

\section{Daftar Rujukan}

Akbar G. dan Tjendrowaseno T.I., 2015, Website Profil Sekolah Sebagai Media Informasi dan Promosi., Indonesian Journal on Networking and Security (IJNS), Vol. 4, No. 1, pp:34-38.

Dolly I dan Lilis N., 2018, Pengembangan Masyarakat Pada Pelaku Usaha Industri Abon Ikan Gabus Berbasis Web Di Kel.Bontoparang Kec.Parangloe Kab.Gowa, Jurnal Balireso Vol. 3, No. 1, Januari 2018.

Mutia T.K dan Desiningrum D.R.,2015, Pengaruh Metode Mulrisensori Dalam Meningkatkan Kemampuan Menghafal Kata Pada Anak Tunarungu Taman Kanak-Kanak (Studi Eksperimental di TK SLB Negeri Semarang)., Jurnal Empati, Vol. 4, No. 1, pp:188-194.

Sejati A.W dan Yumpi-R F., 2016, Pengaruh Multisensori Terhadap Kemampuan Mengingat Huruf Alfhabet Pada Siswa Kelompok Bermain Di Sekolah Cahaya Nurani Jember., Jurnal Pemikiran dan Penelitian Psikologi, Vol. 12, No. 2, pp:21-38.

Setyawati F.F., 2018, Efektivitas Metode Multisensori Untuk Meningkatkan Kemampuan Membaca Permulaan Pada Anak Tunagrahita Ringan Kelas II SLB Negeri Semarang, Tesis, Fakultas Ilmu Pendidikan, Universitas Negeri Semarang.

Eric, K.A. 2015, QUIZLET2: PENGGUNAAN APLIKASI SMARTPHONE UNTUK SISWA DALAM MENDUKUNG MOBILE LEARNING, Seminar Nasional Pendidikan Bahasa Indonesia 2015, hal:31-38

Hanafi, Hafizul Fahri dan Khairulanuar Samsudin. Mobile Learning Environtment System (MLES): The Case of Android-based Learning Application on Unidergraduates' Learning. International Journal of Advanced Computer Science and Application ,Vol. 3 No3, 2012)

Rahmawati, L. 2012, PERANCANGAN WEBSITE SEBAGAI SARANA PROMOSI PADA MTs MA'ARIF NU 1 AJIBARANG, Jurnal Telematika, Vol. 5 No.2 Agustus 2012, hal 36-48

Irawan, Y., Susanti, N., dan Triyanto, A., W. 2016. Analisis Dan Perancangan Sistem Informasi Sekolah Berbasis Website Untuk Penyampaian Informasi Sekolah Dan Media Promosi Kepada Masyarakat. Jurnal SIMETRIS, Vol. 7 No. 1 April 2016, hal 257-262

Riyadi, Retnadi, dan Supriatna. (2012). Perancangan Sistem Informasi Berbasis Website Subsistem Guru Di Sekolah Pesantren Persatuan Islam 99 Rancabango. Jurnal Algoritma Sekolah Tinggi Teknologi Garut. Vol .9, No.40, hal 1-10

Iqbal, R. A, Fitriani, L. 2016. PERANCANGAN WEBSITE RADAR GARUT DI PERUSAHAAN WAHANA SEMESTA GARUT, Jurnal Algoritma Sekolah Tinggi Teknologi Garut. Vol .13, No.1, hal 170-176 